\title{
Different Combinations Of Legowo And Endemic Fish On Rice And Fish Productivity In Minapadi System
}

\author{
Farah Diana $^{1 *}$, Mahendra $^{2}$ \\ 1,2 Aquaculture Study Program, Faculty of Fisheries and Marine \\ Science, Teuku Umar University, West Aceh, Indonesia \\ *Corresponding Author: \\ Email: farahdiana@utu.ac.id
}

\begin{abstract}
.
Minapadi is a fish rearing system in rice fields that is carried out with rice plants. This study aims to increase the income of farmers with high productivity of rice yields and increase the production of endemic fish. The method used is a Completely Randomized Design (CRD) experiment with 4 treatments and 3 replications. The treatments were: A1B1 (legowo 2:1 and giant prawns), A1B2 (legowo 2:1 and fish exclamation), A2B1 (legowo 4:1 and giant prawns), and $A 2 B 2$ (legowo 4:1 and fish exclamation). This research was conducted for 90 days in the rice fields of Lango Village, Pante Ceureumen District, West Aceh Regency. Parameters observed were rice productivity, fish growth and business analysis. The results showed that the best treatment was A1B1 (legowo 4: 1 and giant prawns) by producing an average value of rice productivity of $5 \mathrm{~kg} / \mathrm{plot}$, and the average value of growth of giant prawns of $3.62 \mathrm{~g} / \mathrm{head}$ and fish of fish of $37.17 \mathrm{~g} / \mathrm{head}$. From the results of this study, the application of the Minapadi system with giant prawns and fish with legowo 4:1 gave a positive impact on the observed parameters $(P<0.05)$ and provided benefits for farmers.
\end{abstract}

Keywords: endemic fish, legowo, minapadi, productivity

\section{INTRODUCTION}

The development of foreign fish introduced from outside Aceh by farmers puts pressure on local indigenous fish populations that have no less potential in terms of quantity and quality. For example, chorus fish (Osteochilus vittatus) [1] and giant prawns (Macrobrachium rosenbergii) [2]. The research team has also succeeded in developing and producing local fish including producing Tawes fish (Barbonymus gonionotus) [3], and fish cry [4]Along with the development development and The rapid increase in population can cause the production area to be increasingly limited that can be used for various fields of fishery business, the area for fish cultivation in the village is also becoming increasingly narrow.So there needs to be an effort to utilize the existing land through intensification. One way that can be done is by implementing the Minapadi system.

The rice planting system by providing a growing space called jajar legowo is able to provide better utilization of sunlight for planting and provide air circulation for 
rice plants. In addition, it can control weeds and facilitate fertilization. A good rice planting system in increasing rice yields is legowo 2:1 and 4:1 [5]

Based on data released by the directorate general of aquaculture, land use for Minapadi cultivation nationally is only 8.3 percent. Therefore, the Ministry of Marine Affairs and Fisheries through the Directorate General of Aquaculture has again promoted the Minapadi cultivation program to support the target of aquaculture production [6]. Based on the foregoing, the writer is interested in conducting a research entitled "Rice and Fish Productivity and Analysis of Minapadi Farming in Legowo Systems and Endemic Fish.

\section{METHODS}

This research was carried out from May to August 2021. The research location was in the rice fields of Lango Village, Pante Ceureumen District, West Aceh Regency from preparation to data collection. The method used in this study is an experimental method and the design used is Completely Randomized Design (CRD).The two factorial was repeated three times.

Factor first tested are:

$\mathrm{A} 1=$ legowo system 2: 1

A2 = legowo system 4: 1

The second factor is:

$\mathrm{B} 1=$ Giant prawns

$\mathrm{B} 2=$ Fish chorus

Combination There are 4 treatments in total, namely: A1B1, A1B2, A2B1, A2B2, This research was conducted in a rice field area with a total of 12 plots with an area per plot of $50 \mathrm{~m} 2$. Make a rice field bund with a height of $60 \mathrm{~cm}$, a base width of $60 \mathrm{~cm}$ and an upper width of $30 \mathrm{~cm}$. While kemalir $50 \mathrm{~cm}$ wide, $40 \mathrm{~cm}$ deep. Rice is planted after 30 days.

The variety used is resistant to waterlogging and pest attack, namely MAPAN. Spacing $25 \times 12.5 \mathrm{~cm}$. The number of seedlings planted $2-3$ stems per clump. The water level is $10 \mathrm{~cm}$. Shrimp stocking was done when the plants were 30 days old with a water level of $10 \mathrm{~cm}$. Stocking density was carried out according to the treatment. Stocking is done in the afternoon to avoid stress fish. The duration of shrimp rearing in the Minapadi system is 90 days with feeding 3 times a day, namely in the morning, afternoon and evening. The maximum dose given is 3\% of the total biomass with the frequency of administration. Shrimp harvest is done 90 days after planting rice. Observation of rice seen from its productivity. While shrimp and fish are seen from their growth

Productivity rice according to [7] is calculated using the formula:

$$
\text { Produktivitas padi }=\frac{\text { Jumlah produksi }(\mathrm{Kg})}{\text { Luas lahan }(\mathrm{ha})}
$$


The calculation of absolute weight growth uses the following [8] formula:

Information :

$$
W=W_{t}-W_{0}
$$

W : Growth absolute weight $(\mathrm{g})$

Wt : Final weight of maintenance $(\mathrm{g})$

W0 : Initial weight of maintenance (g)

The data obtained will be grouped, tabulated, performed statistical tests ANOVA and SPSS to see the effect of the experiment. If there is a significant difference, a further Tukey test will be carried out

\section{RESULTS AND DISCUSSION \\ Rice productivity}

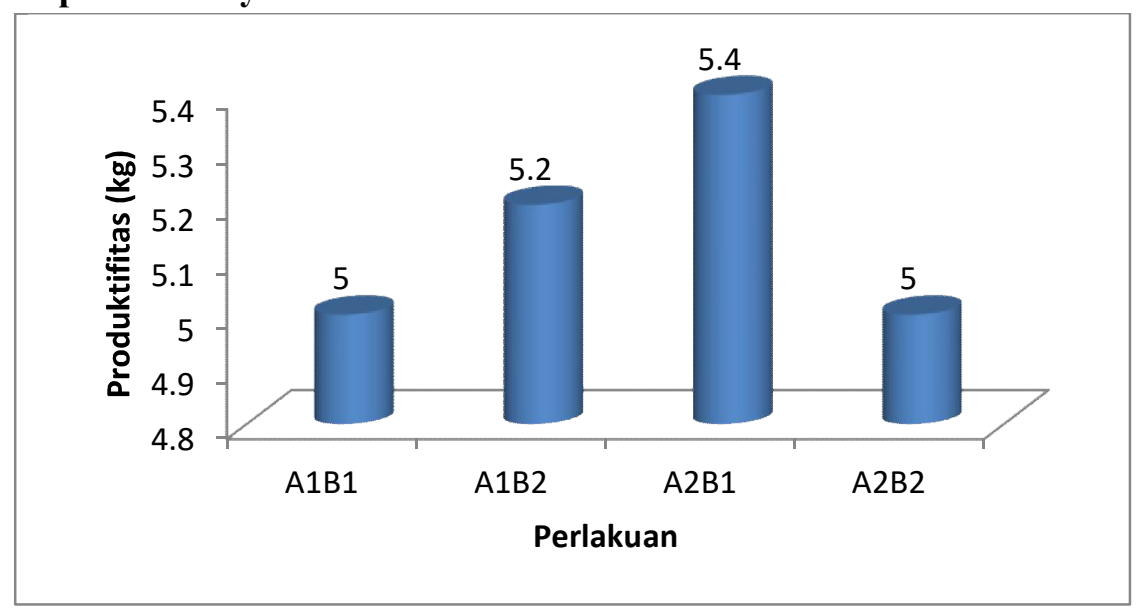

Fig 1. Rice Productivity

Productivity is the process of converting factors of production into a product. Productivity reflects the ratio between total production and land area. The results of the study based on Figure 1 show that the highest rice productivity value in this study was A2B1 treatment (Legowo 2:1 with giant prawns) with an average value of $5 \mathrm{~kg} / \mathrm{plot}$. According to research [9] that through Minapadi there was an increase in land productivity from $5,652 \mathrm{~kg} / \mathrm{ha}$ to $7,612 \mathrm{~kg} / \mathrm{ha}$. The area of rice and Minapadi is the same, but the proportion of Minapadi is $90 \%$ for rice cultivation and $10 \%$ for fish cultivation

According to [10] Minapadi cultivation is said to be successful when rice production is at least the same as production before Minapadi. The ability of land in production is getting better when implementing Minapadi.

Efforts to increase productivity are achieved through improving soil conditions and intensive handling of pests and weeds. The high productivity of rice in the A2B1 treatment is suspected to be the pellet feed given is not consumed by shrimp where the pellets used are the trademark FF999 for fish, so that shrimp prefer abundant 
natural feed. The remaining pellets will accumulate into fertilizer which is absorbed by the rice plant. According to [11] Nitrogen is the main nutrient for plant growth, nitrogen is absorbed by plant roots in the form of NO3 - (nitrate) and $\mathrm{NH} 4+$ (ammonium). Nitrogen deficiency can be bad for plants such as stunted plant growth, yellowing of plant leaves, and limited root system, while excess nitrogen causes vegetative growth to be elongated, easy to fall, reduce grain quality and response to pests and diseases.

\section{Giant Shrimp Growth}

The growth results of giant prawns in each treatment for 90 days of rearing period are presented in Figure 2.

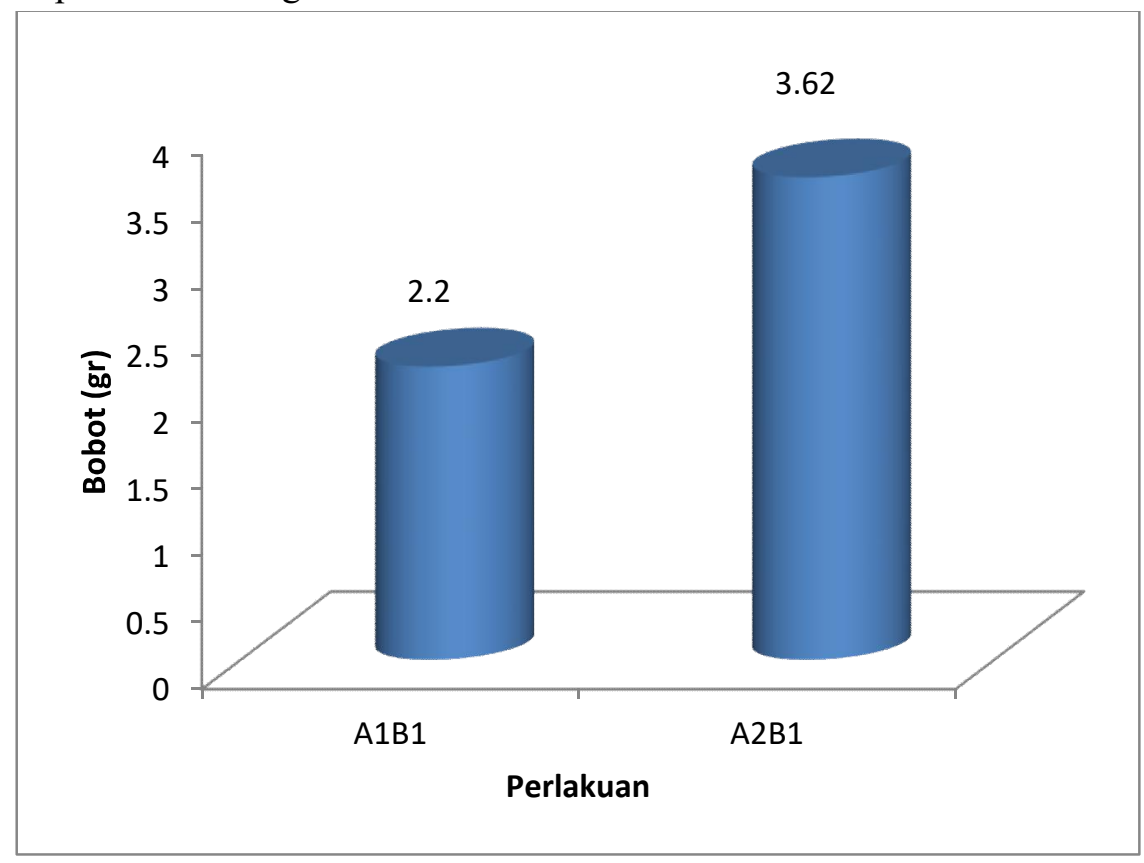

Fig 2. Growth of giant prawns

The results of the study based on Figure 1 showed that the lowest growth value in this study was A1B1 treatment (Legowo 2:1 with giant prawns stocking) with a value of 2.2 gr. Meanwhile, the highest growth value was found in A2B1 treatment (4:1 legowo with giant prawns stocking) with a value of 3.62 gr. The results of this study indicate that the A2B1 treatment plays a role in supporting the growth of giant prawns. Some aspects of physiological processes related to individual growth include regeneration, metamorphosis and moulting. Moulting is the process of periodically releasing old shells and forming new, larger shells. In crustaceans, growth occurs periodically after molting.

Body weight gain will be hampered if it is not preceded by the molting process [12].High growth is characterized by a faster molting process. The process of energy transfer from hemolymph to shrimp shell requires a large amount of energy. This large energy requirement is obtained from the feed consumed. Feeding is an energy 
requirement to support faster growth. This is closely related to growth where if feed consumption is high, there is a lot of energy available that can be used for various life needs and by reducing energy expenditure, so that the portion of energy available for growth is greater. If the physiology of shrimp goes well, including metabolism, then the utilization of feed is more efficient which ultimately increases growth [13]. Therefore, the legowo 4:1 system is more suitable for growth, because of the protection of the rice plant 4 :

\section{Fish Growth Exclamation}

The results of the growth of succulent fish in each treatment during the 90-day rearing period are presented in Figure 3.

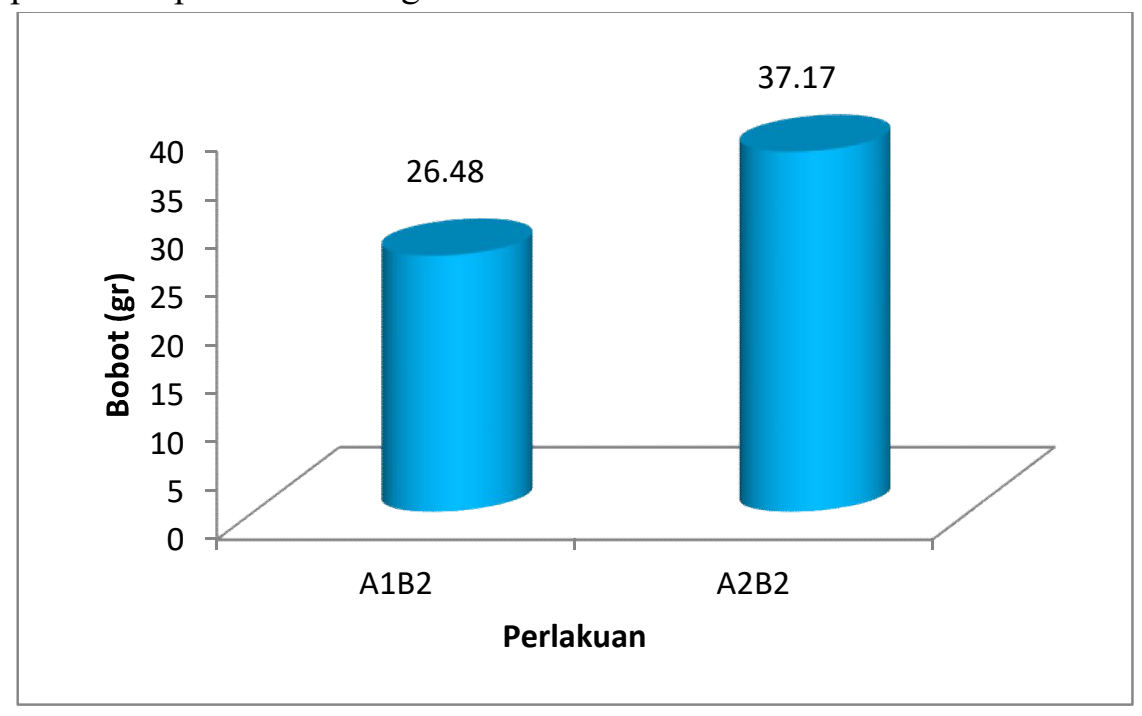

Fig 3. Fish Growth Calligraphy

The results of the study based on Figure 3 it was found that the growth value of the exclamation fish was related to the shrimp where the lowest value in this study was the A1B2 treatment (Legowo 2:1 with the distribution of the chorus) with a value of 26.48 gr. Meanwhile, the highest growth value was found in the A2B2 treatment (4:1 legowo with fish distribution) with a value of $37.17 \mathrm{gr}$. The results of this study indicate that the A2B2 treatment plays a role in supporting the growth of the fish.

The growth of fish and shrimp in Minapadi and Legowo systems was higher with Legowo 4:1 compared to Legowo 2:1. It is suspected that the protection of the legowo 4:1 system of rice plants is more maximal compared to the legowo 2:1 and it is also suspected that the number of kemalir 4: is less, so that the activity of fish such as swimming is reduced, therefore less energy is spent. Feeding is an energy requirement to support faster growth. This is closely related to growth where if feed consumption is high, there is a lot of energy available that can be used for various life needs and by reducing energy expenditure, so that the portion of energy available for growth is greater. If the shrimp physiology goes well, including metabolism, 


\section{Analysis Farmers' income}

Minapadi system farming analysis for farmers needs to be done to find out how much added value can be obtained from the business, then economic analysis is part of finding out whether the system is feasible or not to be developed and to find out whether the Minapadi system provides benefits or not. So below is a simple analysis of the Minapadi farming system which is applied with one business in one growing season.

The assumption of income from the Minapadi system fish farming business is that farmers need $60 \mathrm{~kg}$ of pellets each to raise fish and shrimp. The price of 1 sack of 30 $\mathrm{kg}$ pellets is Rp. 200,000. If the farmer uses $100 \%$ pellets for feed, the cost required is $(60 \mathrm{~kg} / 30 \mathrm{~kg} \mathrm{x} \mathrm{Rp.} 200,000=\mathrm{Rp} .400,000)$. The cost of the farmer's profit if the results obtained are $60 \%$, the cost of income minus the cost of expenses. Where if the assumption of expenditure costs includes the price of 250 giant prawns at a price of @ 500 , as much as $\mathrm{Rp} .125,000$. so that the total assumption issued for giant prawns is (Rp. 400,000+Rp. 125,000 = Rp. 525,000). While the assumption that the results of the expenditure on the fish of chorus includes 250 fish with a price of @ 1000 , as much as Rp. 250,000 so that the total assumption issued is $(\mathrm{Rp} .400,000+\mathrm{Rp} \cdot 250,000=\mathrm{Rp}$. $650,000)$.

Farmers' incomes other than rice yields are assumed to yield $60 \%$ of the stocking density of 150 shrimp and fish each with a yield range of 20 per kilogram of shrimp, so the final yield of shrimp is $7.5 \mathrm{~kg}$, with a selling price of Rp. .185.000/kg [14]. The total selling price for shrimp is $(7.5 \mathrm{~kg} \mathrm{x} 185,000 / \mathrm{kg}=\mathrm{Rp} .1,387,500$. So the total profit income for shrimp is (Rp. 1,387,500 - Rp. 525,000 = Rp. 862,500. While for fish with $60 \%$ yields, fish with a yield range of 10 per kilogram of fish, the final yield of fish is $15 \mathrm{~kg}$, with the selling price of fish Rp. 60,000/ $\mathrm{kg}$ (local market price) The total selling price of fish is $(15 \mathrm{~kg} \mathrm{x} \mathrm{Rp} .60,000 / \mathrm{kg}=\mathrm{Rp} .900,000$. So the total profit income for fish is $(\mathrm{Rp} .900,000-\mathrm{Rp} .650,000=\mathrm{Rp}$. 250,000.The results above are for 1 rice field plot measuring $5 \times 10 \mathrm{~m} 2$, so that the results of this study are 16 plots of rice fields ( 8 plots for shrimp and 8 plots for fish). Therefore, the results obtained by farmers other than rice ranged, among others, for shrimp (Rp. 862,500 × $8=\mathrm{Rp}$. 6,900,000). As for fish it is (Rp. $250,000 \times 8=$ Rp. 2,000,000)So, the total that farmers get is (Rp. $6,900,000+$ Rp. $2,000,000=$ Rp. $8,900,000)$, these results are in addition to the rice harvest. Farmers' profits can be large if the Minapadi system is applied with a large and wide number of paddy fields, so that the stocking density is higher

\section{CONCLUSION}

Minapadi's 4:1 legowo system has an effect on the growth of giant prawns and fish exclamations. with produce the average value of rice productivity as big as 5 $\mathrm{kg} / \mathrm{plot}$, and the average value of the growth of giant prawns is $3.62 \mathrm{~g} / \mathrm{head}$ while the growth of the fish is $37.17 \mathrm{~g} /$ head. 


\section{ACKNOWLEDGMENTS}

The author's research was funded by internal research grants from Teuku Umar University, especially LPPM and Quality Assurance as well as the Aquaculture Study Program, Faculty of Fisheries and Marine Sciences.

\section{REFERENCES}

[1] Aceh Maritime Affairs and Fisheries Service. 2015. Identification of Endemic Fish Species in Aceh Waters South West Region (West Aceh). Final report. Banda Aceh

[2] Erlangga, 2016. Distribution of Giant Giant Shrimp (Macrbrachium rosenbergii) on the East Coast of Aceh. The Terubuk Fisheries Periodic Journal. 44(1): 56-68

[3] Diana, F and Safutra, E. 2018. The Effect of Different Natural Feeding on Tawes (Barbonymus gonionotus) Seeds on Growth and Survival. Journal of Aquaculture. 2(1):1-9

[4] Mahendra and Supriadi. 2019. Rate Growth of Seurukan Fish (Osteochilus vittatus) Larvae By Giving Poultry Egg Yolks. Journal of Aquaculture

[5] Bobihoe, J. 2013. The Jajar Legowo Rice Planting System. Jambi Agricultural Technology Study Center (BPTP). ISBN : 978-602-1276-01-3

[6] Ministry of Marine Affairs and Fisheries. 2018. Minapadi System Fish Cultivation. Directorate General of Aquaculture. Jakarta

[7] Silamat, E., Yuwana., and Yuliarso, MZ 2014. Analysis of Paddy Rice Farming Productivity Using Hand Tractors and Conventional Methods in Rejang Lebong Regency. Bengkulu University. ISSN: 1412-8837

[8] Thu, EVT, Rahman, M., Phoo, WW, and Kim CH 2019. Salinity Effects on Growth and Survival of the Polychaete Rockworm Marphysa sanguinea (Montagu, 1813) Juveniles and Adults. Journal of Aquaculture Research \& Development. 10(2): 1-7

[9] Julistia, DR 2017. Analysis of Minapadi Farming Income in Margoluwih Village, Seyegan District, Sleman Regency. [Essay]. Bogor: Bogor Agricultural University.

[10] Tysno, LFI 2018. Analysis of Minapadi Farming Income. [Essay]. Bogor: Bogor Agricultural University

[11] Kaya, E. 2013. Effect of Straw Compost and NPK Fertilizer on N-Available Soil, NUptake, Growth, and Yield of Paddy Rice (Oryza sativa L). Agrologia, 2 (1): 43-50

[12] Affandi, R. and Tang, UM. 2002. Physiology of Aquatic Animals. Riau University, Riau.

[13] Zaidy, AB 2007. Utilization of Aquatic Calcium in the Molting Process and Its Consequences for the Growth of Giant Prawns (Macrobrachium rosenbergii de Man). Dissertation. Bogor Agricultural University, Bogor.

[14] Coal and Gustianty. 2016. Growth Rate and Survival of Giant Prawns (Macrobranchium rosenbergii de Man) Laboratory Scale. Asahan University. Range 